\title{
Analisis Nilai Produksi pada Industri Kerajinan Tangan di Desa Tutul Kecamatan Balung Kabupaten Jember
}

\author{
(Analysis Of The Value Of Production In The Handicraft Industry In The Village Tutul \\ Subdistrict Balung District Jember)
}

\author{
Meila Nasih Amlauni, P Edi Suswandi ${ }^{1}$, Moh Adenan \\ Jurusan IESP, Fakultas Ekonomi dan Bisnis, Universitas Jember (UNEJ) \\ Jln. Kalimantan 37, Jember 68121 \\ E-mail : edisuswandi.fe@gmail.com
}

\begin{abstract}
Abstrak
Permasalahan utama dalam penelitian ini adalah tentang nilai produksi pada industri kerajinan tangan di Desa Tutul Kecamatan Balung Kabupaten Jember. Penelitian ini bertujuan untuk untuk menguji ada tidaknya hubungan antara variabel nilai modal, nilai upah dan jumlah tenaga kerja terhadap nilai produksi secara empirik. Jenis penelitian ini adalah analisis explanatory Survey. Jenis data dari penelitian ini adalah data primer, meliputi data jumlah tenaga kerja upah, modal, dan nilai produksi. Metode penelitian yang digunakan yaitu analisis linear berganda (OLS). Hasil penelitian menunjukkan bahwa jumlah tenaga kerja dan modal kerja berpengaruh terhadap nilai produksi, sedangkan upah pekerja tidak berpengaruh terhadap nilai produksi pada industri kerajinan tangan di Desa Tutul Kecamatan Balung Kabupaten Jember. Hasil penelitian tersebut menunjukkan implikasi bahwa Penggunaan modal oleh para pengusaha kerajinan tangan belum maksimal dan perlu sokongan dari pemerintah, peningkatan modal kerja pengusaha ini juga harus mendapat sokongan dari pemerintah daerah setempat dengan memberikan dan mempermudah fasilitas Kredit Usaha Rakyat (KUR). Industri kerajinan tangan di Desa Tutul juga masih menggunakan mesin tradisional maka dari itu perlu untuk menigkatkan jumlah tenaga kerja dan memperbaiki kualitas kinerjanya.
\end{abstract}

Kata Kunci: Nilai produksi, modal, jumlah tenaga kerja dan upah.

\begin{abstract}
The main problem of this research was about the value of production in the handicraft industry in the village Tutul subdistrict Balung district Jember. This research was aimed to describe the factors that influence the value of production in the handicraft industry in the village Tutul subdistrict Balung district Jember. This research belongs to explanatory survey. This type of data are primary data, including data on the number of labor wages, capital, and production value. The method of this Research is ordinary least square (OLS). The result of this data shows that capital and amount and manpower have affected value of production, but wage haven't affected value of production in the handicraft industry in the village tutul subdistrict Balung district jember. The research showed the implication that the use of capital by entrepreneurs handicraft is not maximized and need a support from the government, the capital should also get support from the local government to provide facilities to Kredit Usaha Rakyat (KUR). Handicraft industry in the village Tutul also still using traditional machines and therefore entrepreneurs need to boost employment and improve the quality of their performance.
\end{abstract}

Keywords: Value of production, amount of manpower, capital and wage.

\section{Pendahuluan}

Industri adalah kegitan ekonomi yang mengolah baha mentah, bahan baku, barang setengah jadi, atau menjadi barang jadi dengan nilai yang lebih tinggi untuk penggunaannya, termasuk kegiatan rancang bangun dan perekayasaan industri. Kelompok industri adalah bagianbagian utama kegiatan industri. Pertama, kelompok industri dasar. Kedua, kelompok industri sedang. Ketiga, kelompok industri kecil (Disperindag, 2010). Klasifikasi industri berdasarkan jumlah tenaga kerja dibedakan menjadi empat, yaitu. Pertama, industri besar, jika memperkerjakan 100 orang atau lebih. Kedua, industri menengah, jika memperkerjakan 20 sampai 99 orang. Ketiga, industri kecil, jika memperkerjakan 5 sampai 19 orang. Keempat, industri mikro, jika memperkerjakan 1 sampai 4 orang (Mudrajad, 2010).

Ada beberapa faktor yang telah menyebabkan industri kecil ini dapat berkembang dengan baik. Faktor pertama adalah modal kerja. Bilas (2008:23) menyatakan bahwa modal kerja sangat berpengaruh terhadap berjalannya operasi suatu perusahaan sehingga modal kerja harus senantiasa tersedia dan terus-menerus diperlukan bagi kelancaran usaha. Faktor kedua adalah bahan baku. Assauri (2000:15) produksi adalah semua kegiatan dalam menciptakan dan menambah kegunaan suatu barang atau jasa. Faktor ketiga adalah tenaga kerja. Menurut Case \& Fair, (2007:144) tenaga kerja merupakan elemen yang cukup penting.

Di Jawa Timur, jumlah industri tahun ke tahun semakin meningkat. Hal ini dapat dilihat dari data menurut BPS Jawa Timur dari tahun 2010 sebesar 742.671 unit hingga tahun 2013 sebesar 803.453 unit (Dinas Perindustrian dan Perdagangan Jawa Timur). Di Kabupaten Jember jumlah industri kecil sebesar 181.147 unit. Dari jumlah tersebut Kecamatan Balung menyumbang jumlah UKM sebesar 7.304 unit. Dari jumlah tersebut, Desa Tutul sebagai lokasi penelitian, jumlah industri kecil sebesar 1.057 unit, jumlah tersebut mendominasi dari jumlah industri kecil di Kecamatan Balung. Dari jumlah industri kecil di DesaTutul, sebesar 969 unit adalah industri kerajinan tangan tasbih,

1 Corresponding Author 
desain tasbih, dan aksesoris manik yang merupakan objek penelitian.

Desa Tutul yang berada di Kecamatan Balung Kabupaten Jember merupakan pusat industri kecil kerajinan tangan dengan memiliki jumlah indsutri kecil paling besar sebanyak 1.057 industri kecil kerajinan tangan. Hal ini menunjukkan pentingnya faktor produksi tenaga kerja karena dengan banyaknya jumlah industri kecil maka akan semakin banyak pula tenaga kerja yang terserap. Mengingat juga bahwa industri kecil di Desa Tutul hampir semua industri masih menggunakan mesin manual dalam proses produksi jadi peran tenaga kerja sangat dibutuhkan untuk mengolah bahan baku.

Pasar tenaga kerja berkaitan dengan konsep upah, permintaan tenaga kerja dan penawaran tenaga kerja. Harga (dalam pembahasan ini disebut upah), merupakan tiga konsep dasar yang selalu dijumpai dalam penelahaan setiap jenis pasar. Sebuah barang atau jasa mempunyai sisi permintaan karena barang dan jasa itu berguna. Barang tersebut akan memiliki penawaran bila jumlahnya terbatas. Ini merupakan syarat supaya barang atau jasa dikategorikan sebagai barang ekonomi. Interaksi antara kekuatan permintaan dan penawaran dalam pasar tenaga kerja, secara bersama-sama menentukan jumlah orang yang akan dipekerjakan dan tingkat upahnnya. Mengutip pandangan Bellante dan Jackson, menyebutkan bahwa permintaan tenaga kerja yang dikehendaki oleh pengusaha atau majikan untuk dipekerjakan. Sedangkan penawaran tenaga kerja dimana pihak pemilik tenaga kerja siap untuk menjualnya di pasar tenaga kerja (Don Bellante \& Mark Jackson (1990).

Teori produksi merupakan teori pemilihan atas berbagai alternatif, terutama menyangkut keputusan yang diambil oleh seorang produsen dalam menentukan pilihan atas alternatifalternatif yang ada. Produsen berusaha dalam memaksimalkan produksi yang dapat dicapainya dengan suatu kendala biaya tertentu agar dapat dihasilkan keuntungan yang maksimal. Produksi juga merupakan suatu kegiatan yang dikerjakan untuk menambah nilai guna suatu benda atau menciptakan benda baru sehingga lebih bermanfaat dalam memenuhi kebutuhan (Suhartini. 2010).

Ada dua pendekatan dalam teori produksi yakni, fungsi produksi dengan satu faktor produksi variabel dan fungsi produksi dengan dua faktor produksi variabel. Teori produksi dengan satu input variabel, yaitu teori produksi sederhana yang menggambarkan tentang hubungan antara tingkat produksi suatu barang dengan modal yang digunakan untuk menghasilkan tingkat produksi barang berbeda dan faktor produksi lain dianggap tetap (upah dan jumla tenaga kerja).

Fungsi produksi Cobb-Douglas dikenalkan oleh Cobb, C.W. dan Douglas, P.H pada tahun 1928 melalui artikel yang berjudul A Theory of Production. Sejak itu fungsi CobbDouglas dikembangkan dan dianggap sangat penting oleh para peneliti dengan sebutan fungsi produksi, fungsi biaya dan fungsi keuntungan Cobb-Douglas. Cobb Douglas adalah fungsi produksi yang paling sering digunakan dalam penelitian empiris (Dominick Salvatore, 1996:215).

Mulyadi (2003:59) mengemukakan bahwa tenaga kerja adalah penduduk dalam usia kerja (berusia 15-64 tahun) atau jumlah seluruh penduduk dalam suatu negara yang dapat memproduksi barang dan jasa jika ada permintaaan terhadap tenaga mereka, dan jika mereka mau berpartisipasi dalam aktivitas tersebut.

Bagi perusahaan tenaga kerja merupakan salah satu faktor produksi yang memegang peranan penting dalam kegiatan industri kerajinan tangan. Penggunaan tenaga kerja bertujuan untuk mengatur dan mengolah bahan baku pada usaha kerajinan tangan. Tenaga kerja merupakan segala kegiatan manusia baik jasmani maupun rohani yang ditujukan untuk kegiatan produksi.

Sutrisno (2007:39) menyatakan bahwa Modal kerja adalah dana yang diperlukan oleh perusahaan untuk memenuhi kebutuhan operasional perusahaan sehari-hari, seperti pembelian bahan baku, pembayaran upah buruh, membayar hutang dan pembayaran lainnya. Menurut Rosyidi (2004:56), modal mencakup uang yang tersedia di dalam perusahaan untuk membeli mesin-mesin serta faktor produksi lainnya. Sedangkan Mankiw (2003:42) mendefinisikan modal sebagai seperangkat sarana yang dipergunakan oleh para pekerja.

Upah adalah imbalan yang diterima pekerja atas jasa kerja yang diberikannya dalam proses memproduksikan barang atau jasa di perusahaan (Payaman J. Simanjuntak, 2011). Menurut Buchari Alma (2012), terdapat beberapa metode penentuan upah, diantaranya yaitu sistem upah menurut waktu, sistem upah menurut prestasi, potongan, persatuan hasil, sistem upah borongan dan sistem upah premi. Metode penentuan upah yang terdapat dalam penelitian ini yaitu upah borongan yang mana jumlah upah borongan yang diterima pekerja dalam satu bulan.

Sesuai dengan teori produksi dengan satu faktor berubah bahwa satu faktor produksi jumlahnya bisa diubah tetapi faktor produksi lain jumlahnya dianggap tetap. Kenyataan pada fenomena diatas, dimana pengusaha industri kecil memiliki jumlah tenaga kerja tetap atau sama. Namun faktor produksi lain yang jumlahnya dianggap berbeda adalah modal. Berdasarkan fenomena diatas, peneliti tertarik untuk melakukan penelitian dengan judul "Analisis Nilai Produksi pada Industri Kecil Kerajinan Tangan di Desa Tutul Kecamatan Balung Kabupaten Jember”.

Hipotesis dari penelitian ini yaitu diduga terdapat hubungan positif antara nilai modal, nilai upah pekerja, dan jumlah tenaga kerja terhadap nilai produksi pada industri kerajinan tangan di Desa Tutul Kecamatan Balung Kabupaten Jember.

Tujuan dari penelitian ini yaitu untuk mengetahui pengaruh nilai modal, nilai upah dan jumlah tenaga kerja terhadap nilai produksi pada industri kecil kerajinan tangan di Desa Tutul Kecamatan Balung Kabupaten Jember

\section{Metode}

\section{Rancangan atau Desain Penelitian}

Jenis penelitian ini adalah explanatory Survey, penelitian ini bertujuan untuk menguji ada tidaknya hubungan antara variabel nilai modal dan nilai upah terhadap nilai produksi secara empirik. Metode penelitian yang digunakan yaitu analisis linear berganda (OLS).

\section{Jenis dan Sumber Data}

Data yang digunakan dalam penelitian ini adalah data primer dan sekunder. Data Primer meliputi data nilai produksi, nilai modal, nilai upah pekerja, dan jumlah tenaga kerja. 
Sedangkan data sekunder meliputi data yang diambil dari Badan Pusat Statistik Kabupaten Jember, Kantor Desa Tutul serta studi pustaka yang berkaitan dengan penelitian ini.

\section{Unit Analisis}

Unit analisis dalam penelitian ini adalah pemilik industri kerajinan tangan tasbih, desain tasbih, dan aksesoris manik di Desa Tutul Kecamatan Balung Kabupaten Jember yang saat ini perusahaannya masih aktif berproduksi berdasarkan faktor-faktor yang mempengaruhi yaitu nilai upah, jumlah tenaga kerja dan nilai modal.

\section{Populasi dan Sampel}

Untuk menentukan besarnya jumlah sampel maka digunakan rumus Slovin sebagai berikut (Sugiyono;57):

$$
n=\frac{N}{1+N e^{2}}
$$

Keterangan:

$\mathrm{n}=$ Jumlah sampel

$\mathrm{N}=$ Jumlah populasi

$\mathrm{e}=$ Toleransi kesalahan dalam menetapkan sampel 20\%

Populasi dalam penelitian ini adalah seluruh pemilik indutri kerajinan tangan di Desa Tutul Kecamatan Balung Kabupaten Jember. Berdasarkan keterangan yang diperoleh Kantor Desa Tutul bahwa jumlah pemilik indutri kerajinan tangan yaitu sebanyak 1.057 orang dengan 5 jenis usaha yang digeluti. Pengambilan sampel dalam penelitian ini mengunakan metode purposive sampling karena metode ini akan memilih sampel yang memenuhi kriteria penelitan dan dapat mendukung penelitian. Maka dari itu, penulis mengambil 3 jenis usaha terbanyak yang digeluti oleh sebagian besar pengrajin di Desa Tutul. 3 jenis usaha yang paling banyak diproduksi yaitu tasbih, desain tasbih, dan aksesoris manik yaitu sebanyak 969 orang. Maka dari itu pengambilan sampel diambil dari jumlah tersebut. Dimana nilai e adalah $20 \%$ dengan taraf kepercayaan $80 \%$. Perhitungannya sebagai berikut:

$$
n=\frac{969}{1+969(0,2)^{2}}
$$

Dari hasil perhitungan yang telah dilakukan, jumlah sampel yang dihasilkan sebesar 24,371. Tetapi peneliti mengambil sampel 30 jiwa. Karena batas pengambilan sampel terkecil dari penelitian yaitu 30 (Supranto, 1993). Responden tersebut adalah para pemilik indutri kerajinan tangan tasbih, desain tasbih dan aksesoris manik di Desa Tutul Kecamatan Balung Kabupaten Jember.

\section{Metode Analisis Data}

Penelitian ini mengunakan metode analisis regresi berganda. Analisis regresi berganda digunakan untuk menaksir dan atau meramalkan nilai rata-rata hitung atau nilai rata-rata variable dependen atas dasar nilai tetap variabel yang menjelaskan diketahui (Gujarati, 2004). Adapun persamaanya sebagai berikut:

$$
\mathrm{Y}=\beta_{0}+\beta_{1} \mathrm{X}_{1}+\beta_{2} \mathrm{X}_{2}+\beta_{3} \mathrm{X}_{3}+\mathrm{e}
$$

Keterangan:

$$
\begin{array}{ll}
\mathrm{Y} & =\text { Nilai Produksi } \\
\mathrm{X}_{1} & =\text { Nilai Modal Kerja (Rp dalam sebulan) } \\
\mathrm{X}_{2} & =\text { Nilai Upah Kerja (Rp dalam sebulan) } \\
\mathrm{X}_{3} & =\text { Jumlah Tenaga Kerja (Jiwa) } \\
\beta_{0} & =\text { Intersep } \\
\beta_{1}, \beta_{2} & =\text { Koefisien regresi parsial } \\
\mathrm{e} & =\text { distubance error/ error term }
\end{array}
$$

\section{Hasil dan Pembahasan}

\section{Hasil}

Dari keseluruhan hasil yang dianalisis menggunakan alat analisis linear berganda, maka akan diperoleh faktor-faktor yang dapat mempengaruhi nilai produksi. Hal tersebut akan ditunjukkan pada Tabel 1.

Tabel 1. Hasil regresi data cross section

\begin{tabular}{lllll}
\hline Variable & Coefficient & Std. Error & t-Statistic & Prob. \\
\hline $\mathrm{C}$ & -7602318. & 2700355. & -2.815303 & 0.0092 \\
$\mathrm{M}$ & 2.215436 & 0.491390 & 4.508511 & 0.0001 \\
$\mathrm{U}$ & 4266.988 & 11736.32 & 0.363571 & 0.7191 \\
$\mathrm{TK}$ & 1197147. & 302439.1 & 3.958306 & 0.0005
\end{tabular}

Berdasarkan Tabel 1 dengan menggunakan regresi data cross section dapat dilihat bagaimana pengaruh variabel independen Modal (M), Upah (U) dan Jmlah Tenaga Kerja (TK) terhadap variabel dependen yaitu Nilai Produksi (NP) di Desa Tutul Kecamatan Balung Kabupaten Jember diperoleh sebagai berikut:

Nilai konstanta sebesar -7602318 artinya nilai produksi akan menurun sebesar Rp. 7602318 apabila variabel nilai upah dan nilai modal diasumsikan konstan.

Pengaruh nilai modal terhadap nilai produksi sebesar 2,21 artinya, apabila terjadi peningkatan nilai modal sebesar Rp.1, maka akan menaikkan nilai produksi sebesar Rp. 2,21.

Pengaruh nilai upah terhadap nilai produksi sebesar 4266.9 artinya, apabila terjadi kenaikan nilai upah sebesar Rp. 1, maka akan menaikkan nilai produksi sebesar Rp. 4266.9.

Pengaruh jumlah tenaga kerja terhadap nilai produksi sebesar 1197147 artinya, apabila terjadi penambahan jumlah tenaga kerja sebanyak 1 orang maka akan menaikkan nilai produksi sebesar Rp. 1197147

\section{Uji Statistik}

Uji F

Uji F digunakan untuk mengetahui adanya pengaruh masingmasing variabel bebas yaitu nilai modal (M), nilai upah (U) dan jumlah tenaga kerja (TK) terhadap nilai produksi (NP). 
Tabel 2. Hasil Uji Simultan (Uji F)

Cross-section fixed (dummy variables)

\begin{tabular}{|c|c|c|c|}
\hline$\overline{\mathrm{R} \text {-squared }}$ & 0.840564 & $\begin{array}{l}\text { Meandependent } \\
\text { var }\end{array}$ & 10622500 \\
\hline $\begin{array}{l}\text { AdjustedR- } \\
\text { squared }\end{array}$ & 0.822167 & S.D.dependent var & 8311226. \\
\hline $\begin{array}{l}\text { S.E.of } \\
\text { regression }\end{array}$ & 3504864 & $\begin{array}{l}\text { Akaikeinfo } \\
\text { criterion }\end{array}$ & 33.10077 \\
\hline $\begin{array}{l}\text { Sumsquared } \\
\text { resid }\end{array}$ & $3.19 \mathrm{E}+14$ & Schwarz criterion & 33.28759 \\
\hline Log likelihood & -492.5115 & $\begin{array}{l}\text { Hannan-Quinn } \\
\text { criter. }\end{array}$ & 33.16053 \\
\hline F-statistic & 45.69149 & $\begin{array}{l}\text { Durbin-Watson } \\
\text { stat }\end{array}$ & 0.940951 \\
\hline $\begin{array}{l}\text { Prob(F- } \\
\text { statistic) }\end{array}$ & 0.000000 & & \\
\hline
\end{tabular}

Hasil regresi diperoleh nilai probabilitas $\mathrm{F}_{\text {hitung }}$ pada Tabel 2, sebesar 0,000. Hal ini menunjukkan bahwa nilai probabilitas $\mathrm{F}_{\text {hitung }} \leq 0,05$ sehingga Ho ditolak dan $\mathrm{Hi}$ diterima. Dengan Ha diterima berarti secara serentak variabel bebas yaitu nilai modal $\left(\mathrm{X}_{1}\right)$, nilai upah $\left(\mathrm{X}_{2}\right)$ dan jumlah tenaga kerja $\left(\mathrm{X}_{3}\right)$ mempunyai pengaruh yang signifikan terhadap variabel nilai produksi (Y).

Uji t

Pengujian koefisien regresi dalam penelitian ini dimaksudkan untuk mengetahui variabel bebas yaitu nilai modal $(\mathrm{M})$, nilai upah (U) dan jumlah tenaga kerja (TK) berpengaruh secara parsial terhadap nilai produksi (NP).

Tabel 3. Hasil Uji t

\begin{tabular}{|c|c|c|c|c|}
\hline Variable & Coefficient & Std. Error & t-Statistic & Prob. \\
\hline$\overline{\mathrm{C}}$ & -7602318 & 2700355 & -2.815303 & 0.0092 \\
\hline M & 2.215436 & 0.491390 & 4.508511 & 0.0001 \\
\hline $\mathrm{U}$ & 4266.988 & 11736.32 & 0.363571 & 0.7191 \\
\hline TK & 1197147. & 302439.1 & 3.958306 & 0.0005 \\
\hline
\end{tabular}

Pada Tabel 3, Nilai modal (M) dan jumlah tenaga kerja (TK) secara parsial berpengaruh signifikan positif terhadap nilai produksi pada industri kerajinan tangan di Desa Tutul Kecamatan Balung Kabupaten Jember, sedangkan nilai upah berpengaruh tidak signifikan positif terhadap nilai produksi pada industri kerajinan tangan di Desa Tutul Kecamatan Balung Kabupaten Jember.

\section{Uji Asumsi Klasik}

Uji Multikolinearitas

Multikolineaitas terjadi karena terdapat hubungan linear atau terdapat korelasi antar variabel independen. Multikolinearitas dapat dideteksi dengan melihat matrik korelasinya. Jika masing-masing variabel bebas berkorelasi lebih besar dari $80 \%(0,8)$ maka terdapat penyakit multikolinearitas.
Tabel 4. Hasil Uji Multikolinearitas

\begin{tabular}{llll}
\hline$\cdot$ & $\mathrm{M}$ & $\mathrm{U}$ & $\mathrm{TK}$ \\
\hline $\mathrm{M}$ & 1.000000 & 0.764377 & 0.609727 \\
$\mathrm{U}$ & 0.764377 & 1.000000 & 0.569855 \\
$\mathrm{TK}$ & 0.609727 & 0.569855 & 1.000000
\end{tabular}

Berdasarkan Tabel 4 dapat dilihat bahwa hubungan antara semua variabel independen berada di bawah 0.80 sehingga dapat disimpulkan bahwa tidak terdapat masalah multikolinearitas dalam model.

Uji Heterokedastisitas

Uji heteroskedastisitas merupakan uji yang digunakan untuk mengetahui apakah kesalahan pengganggu mempunyai varian yang tidak konstan atau berubah-ubah.

Tabel 5. Hasil Uji Heterokedastisitas

\begin{tabular}{lclc}
\hline F-statistic & 1.644237 & Prob. F(3,26) & 0.2035 \\
$\begin{array}{l}\text { Obs*R- } \\
\text { squared }\end{array}$ & 4.783976 & $\begin{array}{l}\text { Prob.Chi- } \\
\text { Square(3) }\end{array}$ & 0.1883 \\
$\begin{array}{l}\text { Scaled } \\
\text { explained SS }\end{array}$ & 2.278329 & $\begin{array}{l}\text { Prob.Chi- } \\
\text { Square(3) }\end{array}$ & 0.5167 \\
\hline
\end{tabular}

Berrdasarkan Tabel 5 menunjukkan uji heterokedatisitas dengan menggunakan uji Glejser dari hasil Tabel 5 menunjukkan bahwa nilai Probabilitas Obs*R-squared menunjukkan nilai 0,1883. Berdasarkan kriteria bahwa nilai probabilitas chi-square lebih besar dari tingkat signifikasi dengan taraf nyata yang digunakan sebesar 0,05 maka persamaan tersebut tidak mengandung heterokedastisitas.

Uji Normalitas

Pengujian normalitas pada penelitian ini dilakukan melalui uji Jarque-Berra dengan perhitungan skewness dan kurtosis

Tabel 6. Hasil Uji Normalitas

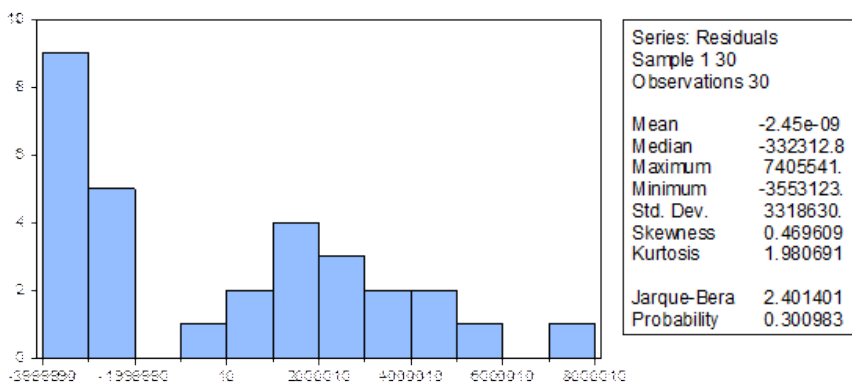

Dari Tabel 6 diketahui nilai Jarque-Berra sebesar 2,401401 dan nilai probabilitas sebesar 0,300983 lebih besar dari $\alpha$ (5\%). Hal ini menunjukkan bahwa model empiris telah berdistribusi normal.

\section{Pembahasan}

\section{Pengaruh Nilai Modal terhadap Nilai Produksi}

Nilai Koefisien regresi variabel nilai modal kerja sebesar 2,85 mengandung arti apabila variabel nilai modal mengalami peningkatan sebesar Rp. 1, maka akan meningkatkan nilai produksi industri kerajinan tangan sebesar Rp. 2,85 dengan asumsi bahwa variabel lainnya dianggap nol atau konstan. 
Faktor nilai modal dalam penelitian ini merupakan faktor yang berpengaruh terhadap jumlah produksi industri kecil kerajinan tangan di Desa Tutul. Dalam penelitian ini diketahui dari masih banyak pemilik usaha kerajinan tangan yang memiliki modal yang terbilang kecil.

Adanya pengaruh nilai modal terhadap nilai produksi usaha kerajinan tangan menandakan bahwa dalam usaha kerajinan tangan sangat tergantung dari modal yang dikeluarkan. Dalam penelitian ini diketahui dari modal yang digunakan untuk proses produksi usaha kerajinan tangan masih masih rendah. Meskipun sudah ada beberapa pengusaha yang berusaha untuk meminjam dana dari instansi keuangan namun biasanya pemilik kurang memprioritaskan kebutuhan akan proses produksi. Hal ini maka usaha kerajinan tangan perlu perhatian khusus untuk memperbaiki sistem permodalan untuk mengefesienkan proses produksi dengan dana yang tersedia tersebut.

Nilai modal mempunyai pengaruh postifi dan signifikan terhadap nilai produksi. Hal ini sesuai dengan penelitian yang disampaikan oleh Yuniartini (2013), dimana modal memiliki pengaruh yang signifikan dan positif terhadap hasil produksi pada industri kerajinan tangan ukiran kayu di Kecamatan Ubud Kabupaten Gianyar.

\section{Pengaruh Nilai Upah terhadap Nilai Produksi}

Nilai Koefisien regresi variabel Nilai upah sebesar 13,70 mengandung arti apabila variabel nilai upah mengalami peningkatan sebesar Rp. 1, maka akan meningkatkan jumlah produksi industri kerajinan tangan sebesar Rp. 13,70 dengan asumsi bahwa variabel lainnya dianggap nol atau konstan. Adanya pengaruh nilai upah terhadap nilai produksi industri kerajinan tangan menandakan bahwa dalam usaha kerajinan tangan sangat tergantung dari nilai upah yang dikeluarkan pemilik usaha untuk tenaga kerja. Dalam penelitian ini diketahui bahwa upah yang diterima pekerja masih sangat minim. Hal ini sebanding dengan harga jual produk yang di setor pada pengepul sangat rendah, padahal permintaan pasar akan hasil produksi indutri kerajinan tangan tinggi.

Hasil analisis data menunjukan bahwa ada pengaruh yang tidak signifikan antara variabel nilai upah terhadap variabel nilai produksi, hasil analisis regresi yang diperoleh dari output regresi, terdapat pengaruh positif antara variabel nilai upah terhadap nilai produksi pada industri kerajinan tangan di Desa Tutul Kecamatan Balung Kabupaten Jember. Berdasarkan analisis tersebut menunjukkan bahwa nilai upah tidak berpengaruh terhadap nilai produksi.

Upah dapat berfungsi sebagai stimulus bagi karyawan, adanya upah yang tinggi, maka karyawan akan bersemangat dalam bekerja, maka produktivitasnya akan meningkat karena pekerja merasa diperlakukan secara adil oleh pengusaha, dengan begitu mereka akan bekerja lebih giat.

Hubungan positif antara nilai upah dengan nilai produksi dikemukankan Widowati (2007) dengan hasil bahwa nilai upah berpengaruh positif dan tidak signifikan terhadap nilai produksi. Dikatakan tidak signifikan karena nilai upah hanya sebatas memenuhi upah minimum regional saja.

\section{Pengaruh Jumlah Pekerja terhadap Nilai Produksi}

Dari hasil regresi dapat diketahui bahwa nilai koefesien regresi sebesar 1197147 menunjukkan besarnya elastisitas input jumlah tenaga kerja terhadap hasil produksi pada industri sepatu dan sandal yang artinya kenaikan tenaga kerja setiap 1 orang dengan mengasumsikan input lain (modal dan upah) konstan, akan meningkatkan produksi sebesar Rp. 1197147. Hal ini sesuai dengan teori Cobb-douglas yang menyatakan bahwa output produksi dipengaruhi oleh tenaga kerja. Selain teori Cobb-douglas, terdapat pula penelitian yang oleh Ni Putu Sri Yuniartini dalam Jurnal Jurusan Ekonomi Pembangunan Fakultas Ekonomi Universitas Udayana, dimana hasil penelitiannya menunjukkan bahwa variabel jumlah tenaga kerja mempunyai pengaruh signifikan serta menunjukkan hubungan yang positif/searah terhadap hasil produksi.

Menurut Machfudz (2007:97), Faktor produksi tenaga kerja merupakan faktor produksi yang penting untuk diperhatikan dalam proses produksi. Hal ini sesuai dengan keadaan industri kecil kerajinan tangan di Desa Tutul, dimana jumlah tenaga kerja sangat berpengaruh positif terhadap proses produksi untuk menghasilkan barang.

\section{Simpulan}

Berdasarkan hasil analisis dan pembahasan yang telah peneliti jelaskan maka dapat disimpulkan yaitu nilai modal memiliki pengaruh positif dan signifikan terhadap nilai produksi. Nilai upah memiliki pengaruh positif dan tidak signifikan terhadap nilai produksi. Jumlah tenaga kerja memiliki pengaruh positif dan signifikan terhadap nilai produksi.

\section{Referensi}

Assauri, S. (2000). Manajemen Pemasaran. Jakarta: Rajawali.

Badan Pusat Statistik. (2014). Kecamatan Balung dalam Angka. Jember: BPS.

Bilas, R. (2008). Teori Mikroekonomi. Jakarta: Erlangga.

Buchari, A. (2012). Pengantar Bisnis. Bandung: Alfbeta.

Dinas Perindustrian dan Perdagangan. (2013). Daftar Sentra Indutsri di Kabupaten Jember. Jember: Disperindag.

Don Bellante \& Mark Jackson. (1990). Ekonomi Ketenagakerjaan. Jakarta: LPFE UI.

Fair \& Case. Prinsip-Prinsip Ekonomi Mikro. Jakarta: Erlangga.

Gujarati, D. (2009). Ekonometrika Dasar Buku I edisi 5. Jakarta: Salemba Empat.

Kantor Desa Tutul. (2014, 8 8). Profil Desa Tutul. Dipetik 12 16, 2016, dari DesaTutul.wordpress.com: https://desatutul.wordpress.com/profil-desa/

Machfudz, M. (2007). Dasa-Dasar Ekonomi Mikro. Malang: Prestasi Pustaka Publisher.

Mankiw, N Gregory. 2006. Mikro Ekonomi. Jakarta: Erlangga

Mudrajat, K. (1997). Ekonomi Pembangunan (Teori dan Kebijakan). Yogyakarta: YKPN.

Mulyadi, S. (2003). Ekonomi Sumber Daya Manusia dalam Prespektif Pembangunan . Jakarta: PT. Raja Grafindo Persada.

Rosyidi, S. (2004). Pengantar Teori Ekonomi Pendekatan kepada Teori Ekonomi Mikro dan Makro. Surabaya: Rajawali Press.

Salvatore, Dominicik. 2006. MikroEkonomi Edisi Empat. New York: Mc. Grawhill, Inc

Simanjutak, P. (2011). Pengantar Ekonomi Sumber Daya Manusia. Jakarta: Lambaga Penerbit Fakultas Ekonomi UI.

Sugiyono. (2008). Metode Penelitian Kuantitatif, Kualitatif dan R\&D Bandung: Alfabeta.

Suhartini. 2010. Modul Perkuliahan III Produksi (Teori, Fungsi, dan Efisiensi). Fakultas Pertanian Universitas Brawijaya: Malang

Supranto, J. (1993). Ekonometrik. Jakarta: FE UI 
Sutrisno. (2007). Manajemen Keuangan: Teori, Konsep dan Aplikasi Edisi Satu. Yogyakarta: Penerbit Ekonisia.

Widowati. (2004). Analisis yang Mempengaruhi Faktor-Faktor Nilai Produksi pada Perusahaan Industri Furniture Berskala Besar di Propinsi Jawa Tengah Tahun 2004. Jurnal Ekonomi Pembangunan, 1-16.
Yuniarti, N. P. (2013). Pengaruh Modal, Tenaga Kerja dan Teknologi terhadap Produksi Industri Kerajinan Ukiran Kayu di Kecamatan Ubud. Jurnal Ekonomi Pembangunan Fakultas Ekonomi Universitas Udayana, 1-15. 